\title{
Care, Communication, Learner Support: Designing Meaningful Online Collaborative Learning
}

\author{
Heather A. Robinson, Whitney Kilgore, and Scott J. Warren \\ University of North Texas
}

\begin{abstract}
The purpose of this study was to identify emergent themes regarding higher education instructors' perceptions concerning the provision of collaborative learning activities and opportunities in their online classroom. Through semi-structured interviews, instructors described their teaching experiences and reported specifically about the online collaborative opportunities offered in their online classrooms. A multi-phase coding process was used to analyze the information, including the constant comparative coding method for theme and category development. The three main themes that emerged from this study are: the importance of online communication approaches, challenges and supports for online collaborative learning, and online learner support as the core of online learning. In the online classroom, additional factors must be considered in order to develop successful online collaborative learning. Beyond group work, these considerations include additional time and nurturing, scaffolding, instructional design, and understanding students' comfort level with collaborative online work. The findings of this study are discussed, and recommendations are provided for the development and design of meaningful online collaborative learning.
\end{abstract}

Keywords: care theory, collaborative learning, instructional design, online learning, student support

Robinson, H.A., Kilgore, W. \& Warren, S. J. (2017). Care, communication, learner support:

Designing meaningful online collaborative learning. Online Learning, 21(4), 29-51. doi:

10.24059/olj.v21i4.1240

\section{Designing Meaningful Online Collaborative Learning}

Concurrent with increased technology adoption are pedagogical changes in online learning. Further, interest in the use of collaborative learning in online courses has increased. For example, Kang and Im (2005) recognized that early online learning lacked meaningful interactions. This can be improved, as Vygotsky (1978) proposed, if students are placed in groups based on their level of experience and proficiency. In this case, individuals with less proficiency benefit from the strengths of their more capable peers, and individuals with a higher level of proficiency benefit 
from teaching their less capable peers. Learners with varying levels of proficiency can benefit from such a collaborative experience. Working with peers also allows students to use and improve their metacognitive skills (Ally, 2008). Recent research on online collaborative learning examined how the features of traditional collaborative learning evolve in the online environment. The same features of collaborative learning, such as intentional design, co-laboring of individuals, and meaningful learning are approached differently in an online course than in a face-to-face course (Barkley, Major \& Cross, 2014; Major, 2015). Intentional design is potentially more important in the online classroom. For an instructor, ensuring co-laboring or equal distribution of work and meaningful learning presents a challenge in an online course because of the physical limitations (Barkley et al., 2014; Major, 2015).

Rovai (2004) emphasized quality online education by the integration of best practices and by encouraging instructors to reflect upon and improve their online teaching and course design skills. Successful, instructors "must have a solid understanding of the major principles of online course design before they attempt to put a course together" (Rovai, 2004, p. 82). Online teachers are inclined to educate as they were taught (Cyrs, 1997) and to apply the same approach in the online classroom. However, fundamental differences between the online classroom and the faceto-face classroom (i.e. the physical limitations; communication; course design and delivery) make it a mistake to teach an online course the same way an instructor would teach a face-to-face course (Rovai, 2004).

It is therefore critical to find approaches to "support teachers in developing and applying creative and collaborative teaching methods" (Hämäläinen, \& Vähäsantanen, 2011, p. 179), as learner engagement and collaboration in online education continues to be a priority for further research (Kim \& Bonk, 2006; Moore and Kearsley, 2012; Oncu \& Cakir, 2011). The future potential of learning with technology is dependent on "designing new ways to support teachers in orchestrating collaborative learning and creativity, and second, in developing technological environments, which require and support definite collaboration in problem solving" (Hämäläinen, \& Vähäsantanen, 2011, p. 178).

The purpose of this study was to identify emergent themes regarding higher education instructors' perceptions about the provision of collaborative learning activities and opportunities in their online classroom. With synchronous, Web- and cloud-based applications (i.e. conferencing applications and collaborative document development opportunities), options for developing collaborative learning activities continually expand. Central to this case study was to identify how instructors in higher education who teach fully online courses offered collaborative student opportunities. This endeavor used instructors' own words to gain insight into their lived instructional experiences. The topics of inquiry under investigation were:

- What are the perceptions of instructors in higher education toward collaborative learning in the online classroom?

- What experiences do faculty members identify concerning online collaborative learning?

- What tools do higher education instructors integrate into their pedagogy for collaborative learning in the online classroom?

- How do online instructors presently provide collaborative learning opportunities in the online classroom? 
Care, Communication, Learner Support:

Designing Meaningful Online Collaborative Learning

\section{Review of Related Literature}

Teaching and learning in an online environment permits participants the opportunity to apply new technologies, collaborate with others, and take advantage of flexible schedules (Johnson, 2013). However, teaching and learning in an online environment require a redefinition of roles for both instructors and learners (Anderson, 2008; Keengwe \& Georgina, 2012; Johnson, 2013). The online instructor has an important role as a facilitator that establishes a constructivistbased learning environment which can encourage collaboration that supports the achievement of learning objectives (Rovai, 2004). Activities and group work in the online classroom require additional considerations and modifications beyond the typical face-to-face classroom. This reality requires instructors to consider alternative solutions to communicate, collaborate, and clarify written instructions. For example, Vonderwell and Turner (2005) reported that students want clear and effective communication of online messages and instruction. The delay factor and lack of interaction in asynchronous communication can negatively influence student learning (Kang \& Im, 2005; Vonderwell \& Turner, 2005).

The belief that advances in technology, connection speed, and the availability of collaborative tools will lead to new and improved online collaboration and address some shortcomings of traditional or early online learning and its static nature, has resulted in new research. Web-based tools provide many opportunities for small group collaboration that some online instructors have adopted and integrated into their online classroom to facilitate collaboration.

\section{Constructivism and Social Constructivism}

A learner brings a unique set of experiences and beliefs about the world into the constructivist epistemology (Smith \& Ragan, 2005; Tam; 2009) and cannot be directed or led to expand their understanding (Von Glasersfeld, 1989). Rather, the learner gains understanding through interactions with the environment and peers, similar to, and emerging from, Vygotsky's conceptions; this is a core concept of constructivism according to Savery and Duffy (1995). What is learned and how it is learned are not separated in this view. All learning involves cognitive construction of concepts, regardless of what is taught, according to constructivists (Swan, 2005). Learners expand their understandings or new knowledge by building upon prior knowledge and by testing their beliefs to determine whether the information and knowledge constructs have utility through a process of regular critique that rejects knowledge that no longer holds and relegates it back to information without current value.

Social constructivists extend the constructivist worldview and believe that language, collaboration, and interaction play an important role in thinking and learning (Swan, 2005). Further, they believe "groups construct knowledge, collaboratively creating a culture of shared meanings" (Barkley et al., 2014, p. 17). Students working in groups can pool their knowledge, as the knowledge of a group combined is greater than that of an individual.

\section{Online Learning}

Online education "lies in the junction of distance education, human-computer interaction, instructional technology, and cognitive science" (Larreamendy-Joerns \& Leinhardt, 2006, p. 568). Instructional design is another aspect to be included in this list. Classroom instruction sets the standard for the delivery of online courses that possess academic excellence and incorporate "sound cognitive and instructional principles" (Larreamendy-Joerns \& Leinhardt, 2006, p. 571). 
During the infancy of online learning in the early 1990s, social interactions experienced during a traditional face-to-face course with peers and instructors were generally converted into email communications and discussion or forum postings, with far less overall interaction (Van Bruggen, 2005). These content-heavy, independent study courses left little time or opportunity for meaningful interaction and collaboration.

In a learner-centered context, the online classroom instructor should understand the prerequisite knowledge held by each student (Anderson, 2008). These prerequisite skills are not overlooked in a constructivist learning environment; rather, higher order goals incorporate entrylevel goals, and scaffolding is provided as necessary (Driscoll, 1994). Several practice implications for the improvement of online learning, as provided by Stodel, Thompson, and MacDonald (2006), are an important part of the learner-centered context. These implications include: coaching learners on how to learn online, creating opportunities to enhance spontaneity and emergent design, articulating and managing the expectations of the online community, and attempting to understand all learners in online learning environments.

\section{Collaborative Learning}

Collaborative learning occurs in "a learning environment in which individual learners support and add to an emerging pool of knowledge of a group; emphasizes peer relationships as learners work together creating learning communities" (Moore \& Kearsley, 2012, p. 305). The term "collaborative learning" corresponds with Vygotsky's (1978) theory of learning, specifically the zone of proximal development (ZPD) in which a shared understanding can be developed during this learning process. In the online environment, "...collaborative learning comprises the same indispensable features as onsite collaborative learning, but they typically unfold differently" (Barkley et al., 2014, p. 5).

Online learning is best accomplished through collaboration and participation, which drives online learning, according to Hrastinski (2009). Three separate studies of 26 online courses at the New Jersey Institute of Technology determined that participation in collaborative learning correlates to higher learning outcomes when compared with those in traditional settings (Hiltz, et al., 2000).

When students are actively involved in collaborative (group) learning on-line, the outcomes can be as good as or better than those for traditional classes, but when individuals are simply receiving posted material and sending back individual work, the results are poorer than in traditional classrooms

Collaborative learning and cooperative learning are terms often used interchangeably. While the terms have similar meanings, distinct differences exist. Online group activities do not "automatically result in collaborative interactions" or online collaborative learning, as instructors may believe (Paulus, 2005, p. 113). This technology determinism, or a "belief that because learners now can interact more frequently, they automatically will" is a side effect of the availability of various and emerging technology tools (Paulus, 2005, p. 102).

Group learning occurs in a larger group as compared to collaborative learning. Early examples of online group learning were typically asynchronous in nature and included the use of discussion threads that allowed students to discuss and pose questions to group members (Henri $\&$ Rigault, 1996; Paulus, 2005). Collaborative and cooperative learning groups are smaller, usually with fewer than six members. Further, cooperative learning utilizes a division of labor approach 
and members of a group choose certain tasks to complete individually (Henri \& Rigault, 1996). In collaborative learning, students work together to increase understanding and reach a common goal with support from the instructor; as group members share various perspectives, individual awareness of thought process develops (Arvaja, Salovaara, Häkkinen, \& Järvelä, 2007; Bento \& Schuster 2003). Mutual respect for group members and recognition of the individual abilities that each group member possesses are essential components of a collaborative learning process (Hathorn \& Ingram, 2002).

The instructor role is "significant in the enhancement of productive collaboration processes" (Hämäläinen, \& Vähäsantanen, 2011, p. 179). Much of the current research focus about online collaborative learning is on student learning, specifically, online collaborative learning from a student perspective, the tools used to support collaborative learning, and instructors' ability to respond to the needs of students in order to provide these learning opportunities (Capdeferro \& Romero, 2012; Coll et al., 2014; Kai-Wai Chu \& Kennedy, 2011; Thompson \& Ku, 2006). Assessing learners' readiness for computer-supported collaborative learning (CSCL) through the development of a framework measuring motivation for collaborative learning, prospective behaviors for collaborative learning, and online learning aptitude was the focus of one recent study (Xiong, So, \& Toh, 2015). The use of social media, Mendeley, and virtual environments have provided additional areas of current research, exploring how students interact, whether student academic performance is improved, and how or whether tools support students in online collaborative learning (Al-Rahmi, Othman \& Yusuf, 2015; Khwaja \& Eddy, 2015; Vuopala, Hyvönen, \& Järvelä, 2016).

A gap in current research relates to faculty perspectives on the integration of online collaborative learning. Additional research with heightened attention to how to support instructors' "abilities to apply creative and collaborative working methods" is needed (Hämäläinen, \& Vähäsantanen, 2011, p. 179). There is also a need to offer teachers concrete resources to orchestrate collaborative teaching methods, provide administrative and work culture support for these methods, and a "need to highlight the autonomy of teachers' abilities to apply creative and collaborative working methods" (Hämäläinen, \& Vähäsantanen, 2011, p. 179).

Implementing social constructivism in an online classroom is a substantial task. To do it well, an online instructor must understand the theoretical principles and design models for constructivist pedagogy and be familiar with the approaches for providing a rich, learner-centered environment for active learning. Interaction and collaboration are different in an online classroom compared with a face-to-face classroom, although best practices have gradually begun to emerge. Many instructors have used asynchronous learning activities since the advent of online college courses, which support increased reflection and cognitive effort. However, synchronous learning opportunities are more available today because of technological advances; tools such as Blackboard Collaborate, BigBlueButton in Canvas, Adobe Connect, and GoToTraining, are now widely available. Improved understanding of how instructors use such methods forms the basis of this study. 


\section{Methods}

\section{Procedures}

A descriptive design with four unique cases was used as the qualitative approach for this study. Each participant functioned as a separate case since multifaceted experiences, including setting and pedagogical approach, led to individual, subjective outcomes. This is not to say that the cases were structurally idiosyncratic; rather, the individual cases were bound by the commonality of online learning as a shared practice, while the interviews focused on care expressions in digital delivery settings made within each instructor case. Therefore, it was possible to explore similarities and the themes that emerged across these cases (Ravitch \& MittenfelnerCarl, 2016).

Such qualitative studies are naturalistic and use an interpretive practice to consider how social experiences are created (Denzin \& Lincoln, 2005). A case study is empirical inquiry that "investigates a contemporary phenomenon in depth and within a real-world context, especially when the boundaries between phenomenon and context may not be clearly evident" (Yin, 2014, p. 16). The "particularity and complexity of a single case" is further studied to understand the importance of the case (Stake, 1995, p. xi). Since the topics and subtopics of inquiry were how and why questions regarding a contemporary phenomenon, case study research was the preferred method for such an inquiry (Yin, 2014). Further, more than one source of evidence was used; four instructors from two universities were studied, and cross-comparison of their care expressions enriched the overall thematic development.

In this type of research, the wealth of information derived from a case study and its closeness to real-life situations are important in two respects, according to Flyvbjerg (2005). First, case studies are "important for the development of a nuanced view of reality, including the view that human behavior cannot be meaningfully understood as simply the rule-governed acts found at the lowest levels of the learning process..." (Flyvbjerg, 2005, p.303). Second, case studies help the researcher's learning process and development of research progression. Further, case studies are appropriate for learning and can be a "route to knowledge" (Campbell, 1975, p. 191) and more in-depth learning surrounding a phenomenon or case.

The researcher sought to understand the phenomenon of collaborative learning in online education. To understand what this looks like, how it happens, and how it is defined for online learning today, a case study is appropriate. The "detail, richness, completeness..." of such exploration of a phenomenon during a case study are the strengths of this type of research (Flyvbjerg, 2005, p. 314).

\section{Information sources}

The participants for this study were four female higher education instructors who teach fully online graduate courses and use collaborative learning in their courses. Originally, eight male and female participants were contacted and recruited through e-mail from two research institutions. Purposive sampling was used to identify and recruit instructors for the semi-structured interviews who teach online and provide collaborative learning opportunities in their online classroom. Further, participants taught at the graduate level, significant because the class size of fully online graduate courses is potentially smaller than undergraduate courses. To locate potential participants, peers and colleagues were contacted and discussions were held regarding the purpose of the dissertation study. Colleagues from both universities provided names and email addresses of 
potential participants. Multiple attempts over several months were made to recruit and interview at least one male participant, but this was unsuccessful. Primary source information for the study was obtained by semi-structured interviews. Table 1 summarizes the demographics of the participants, and pseudonyms are used.

\section{Teaching Online Online Learning Present Work Goals}

\begin{tabular}{|c|c|c|c|}
\hline $\begin{array}{l}\text { Abby, } \\
\text { Ph.D. }\end{array}$ & 8 years & $\begin{array}{l}\text { Appreciates the flexibility } \\
\text { of teaching online; extra } \\
\text { effort is needed to keep } \\
\text { students engaged }\end{array}$ & $\begin{array}{l}\text { Primary goal is to help her } \\
\text { students }\end{array}$ \\
\hline $\begin{array}{l}\text { Catherine, } \\
\text { Ph.D. }\end{array}$ & 8 years & $\begin{array}{l}\text { Strives to provide a } \\
\text { connected or human } \\
\text { element to her online } \\
\text { classes }\end{array}$ & Seeks tenure and promotion \\
\hline $\begin{array}{l}\text { Susan, } \\
\text { Ph.D. }\end{array}$ & 11 years & $\begin{array}{l}\text { Likes the flexibility of } \\
\text { teaching and collaborating } \\
\text { online, but challenges are } \\
\text { presented in the } \\
\text { preparation time for online } \\
\text { instructors }\end{array}$ & $\begin{array}{l}\text { Mentors those in her } \\
\text { department and in her field } \\
\text { to continue the growth of } \\
\text { the field }\end{array}$ \\
\hline $\begin{array}{l}\text { Elizabeth, } \\
\text { Ph.D. }\end{array}$ & $10+$ years & $\begin{array}{l}\text { Appreciates meaningful } \\
\text { conversations and learning } \\
\text { with and from her students }\end{array}$ & $\begin{array}{l}\text { To maintain and increase } \\
\text { student enrollment and } \\
\text { retention in her department }\end{array}$ \\
\hline
\end{tabular}

Table 1. Participant Demographics.

\section{Analysis}

The researcher role was that of a human instrument, specifically, the primary research instrument (Erlandson, Harris, Skipper, \& Allen, 1993). The researcher verbally and analytically investigated participants' views in order to build broad themes and generate interconnected themes. The researcher audited all information, notes, and documentation. She remained responsive to new insights that arose and expanded the scope of research as needed to confirm or enhance meaning from each phase of the study. The researcher followed Lincoln's (1985) recommendation with regard to establishing trustworthiness and credibility: truth value (credibility), applicability (transferability), consistency (dependability), and neutrality (objectivity).

To establish confidence in the "truth" (truth value) of the findings, member checking was used once the interviews were transcribed and again once categories and themes were analyzed and findings were recorded. Peer debriefing sessions were used to discuss emerging themes and develop explanations aloud (Erlandson et al., 1993). These working sessions and discussions were also used to reach inter-coder agreement on any code or category questioned during coding. Applicability or transferability was established through the use of thick, rich description of each phase of the study. Further, transferability "takes the place of generalizability as a criterion for 
making a judgment regarding rigor in constructivist studies" (Lincoln \& Guba, 2013, p. 80). The written findings report accurate accounts of the semi-structured interviews, including the use of direct quotations of faculty members and instructors interviewed. Purposeful sampling was used in this study for transferability (Lincoln, 1985).

Consistency was implemented, as the researcher coded and analyzed when well rested and not distracted. An audit trail to organize information collection and phases of the analysis was an important component of this study (Merriam, 2009). An analytic memo was used during the interviews, during post-interview reflection, and during the analysis and coding processes and phases. Neutrality or objectivity was established during the analysis and recording of the findings. A subjectivity statement was developed so that the researcher could better understand and reflect upon personal biases before interviewing and analysis and interpretation.

Multiple coding phases and processes were used for information analysis in the study. This included In Vivo, Attribute, Initial, Descriptive, and Structural coding in the first phase, and the constant comparative analysis to combine codes in a second phase of analysis. The researcher used the guidance of Lincoln (1985), Glaser and Strauss (1999), and Saldaña (2009) to analyze the information gathered from the interviews. The first phase of the coding process began with hand coding individual interviews using the voice of the participant through In Vivo, Initial, and Descriptive coding methods (Saldaña, 2009). Highlighting important participant quotations and dividing sections that pertained to each topic of inquiry was accomplished using Structural coding.

All codes and pertinent highlighted sections were combined for further analysis, comparison, and reduction or saturation following a constant comparative method in the second phase of analysis. A second pass through the data corpus was conducted to accomplish this. The researcher combined evidence from the previous steps to address the developmental theory from the constant comparative process (Glaser \& Strauss, 1999). Lincoln (1985) referred to this process in terms of "construction" versus theory, as in an initial construction phase of potential theory development. Creswell (2013) explained the constant-comparative process and phases as a zigzag process surrounding one core phenomenon, during which the researcher moves back and forth between phases of analysis. The entire data corpus was used when constructing the theory for this stage. As categories were narrowed and major themes developed from the coding phases, they were used as section titles to organize the findings of this case study. Further, predominant themes were analyzed to determine how, or whether, each related to a specific topic of inquiry, and support was provided for each placement in the write up of the findings.

During the multi-phase analysis, nine top categories were identified and further analyzed to determine how each related to the topics of inquiry. These nine categories were compressed into three themes based on further evaluation of online collaborative learning conducted with the aid of two other trained analysts who helped to eliminate underlying duplicate codes, to reduce or merge categories, and to confirm identified themes.

\section{Findings}

Nine categories were developed in the multi-phase analysis process of this study: (1) Working in Groups; (2) Nurturing, Helping, and Supporting Students; (3) Technology Tools; (4) Challenges in Online Learning; (5) Synchronous; (6) Scaffolding; (7) Relationships with Students; (8) Communication; and (9) Asynchronous. Figure 3 provides a display of these categories. The categorical placement flows clockwise in this figure from the most instances (Working in Groups) to the least (Asynchronous). 


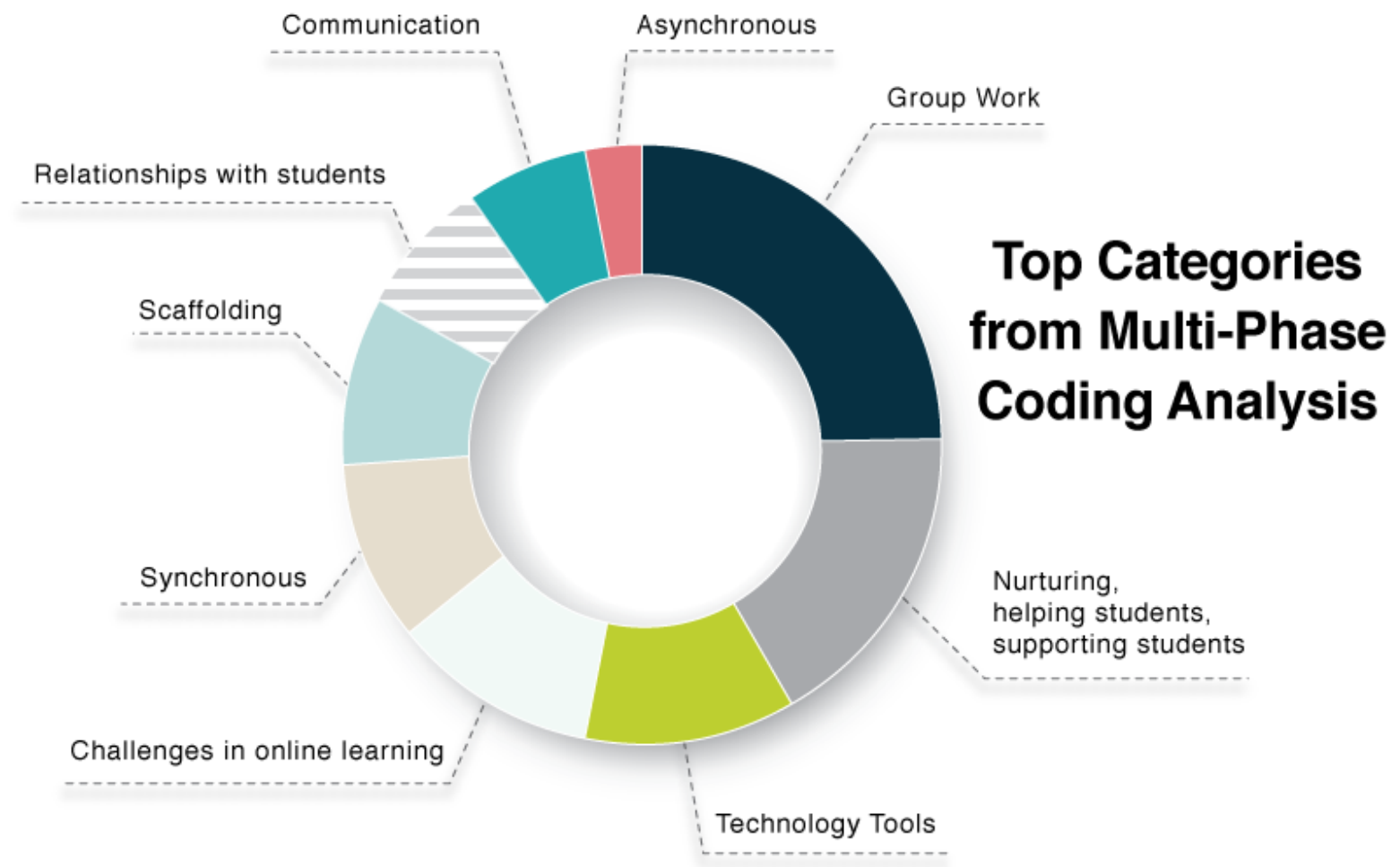

Figure 1. Top categories

The three main themes that emerged from this study were: the importance of online communication approaches, challenges and supports for online collaborative learning, and that care is at the core of online learner support. In terms of participants and their relation to online teaching, Abby, Catherine, Susan, and Elizabeth stated that they each enjoy teaching online and recognize the flexibility offered in this learning environment for themselves and their students. Both Elizabeth and Catherine noted that this is not the case for all online instructors and that online teaching may not be a good fit for every instructor. All four participants discussed various challenges and obstacles that confront online instructors. Collaborative learning is at the heart of this case study, and each participant defined and explained this type of learning. They described it as a process of working and learning together on an authentic endeavor, and building mutual understanding and knowledge.

Overall, participants expressed the perception that collaborative learning in the online classroom presents challenges but is nonetheless achievable. Online collaborative learning can be as effective, and can occur in the same manner, as face-to-face collaborative learning. However, accommodations should be made by instructors and designers in consideration of distance and various other online challenges. Each participant in this study continues to refine and improve her approach to collaborative learning. All participants shared specific concerns. 
One major concern was explained by Elizabeth who stated that, "I think it takes more time [online]. It also takes a great deal of commitment on both parties to really develop a collaborative environment when you start online." She assessed that students may not be comfortable working together in an online setting but accommodated her students and alleviated anxiety through a variety of methods, including humor, versatility, and support. Susan reaffirmed Elizabeth's concern that students may not be comfortable working together online. She observed that students do not care for collaborative activities, although she continues to provide them in order to prepare students for future online courses where, she believes, they will be expected.

Abby discussed the logistical challenges of online students working in groups: "you cannot get together physically...to solve an issue or to just talk about something or to share materials." She believes that instructors who provide collaborative learning must consider schedules and time zones. Catherine handles the issue of different time zones by grouping students in pairs so as not to "damper progress."

In order to support student task engagement, participants explained that their students work in small groups with fewer than four members on authentic and real-world problems and projects that demonstrate their relevance. Although the level of structure provided for collaborative learning varied among the participants, all utilized scaffolding and/or modeling, as well as an assortment of tools for collaborative learning. These range from the tools within the learning management system (LMS) to three-dimensional virtual environments. Abby explained that when evaluating a potential tool for the online classroom she investigates its capabilities. "I see...its affordances and how it can be used. I also try to read what everyone else is saying about the tool... [and] how teachers are using it in the classroom."

Regarding synchronous and asynchronous collaborative learning opportunities and instructor communications, participants were equally divided. Catherine and Susan reported more asynchronous activities while Abby and Elizabeth offered more synchronous activities and communication. See Table 2 for a summary of findings overview organized by topic of inquiry.

\begin{tabular}{llll}
\hline $\begin{array}{l}\text { Topic of Inquiry 1 } \\
\begin{array}{l}\text { Perceptions toward } \\
\text { collaborative learning }\end{array}\end{array}$ & $\begin{array}{l}\text { Topic of Inquiry } 2 \\
\text { Experiences of } \\
\text { providing } \\
\text { collaborative } \\
\text { learning }\end{array}$ & $\begin{array}{l}\text { Sub-topic 1 } \\
\text { Tools integrated for } \\
\text { collaborative } \\
\text { learning }\end{array}$ & $\begin{array}{l}\text { Sub-topic } 2 \\
\text { Collaborative } \\
\text { learning } \\
\text { opportunities } \\
\text { provided }\end{array}$ \\
\hline $\begin{array}{l}\text { Everything takes more } \\
\text { time online }\end{array}$ & $\begin{array}{l}\text { Critique sessions } \\
\text { with objectives and } \\
\text { modeling }\end{array}$ & 3-D Environments & Aynchronous \\
$\begin{array}{l}\text { Students may not be } \\
\text { comfortable working } \\
\text { together }\end{array}$ & $\begin{array}{l}\text { Moderators for } \\
\text { group discussion } \\
\text { topics }\end{array}$ & GoToMeeting & $\begin{array}{l}\text { Online collaborative } \\
\text { discussions }\end{array}$ \\
$\begin{array}{l}\text { Students need the extra } \\
\text { support }\end{array}$ & $\begin{array}{l}\text { Projects are } \\
\text { culmination of } \\
\text { objectives met }\end{array}$ & Skype & $\begin{array}{l}\text { Online collaborative } \\
\text { student critiques }\end{array}$ \\
& Canvas LMS & $\begin{array}{l}\text { Online meetings and } \\
\text { projects in 3-D } \\
\text { environment }\end{array}$ \\
\hline
\end{tabular}


Care, Communication, Learner Support:

Designing Meaningful Online Collaborative Learning

\begin{tabular}{|c|c|c|c|}
\hline $\begin{array}{l}\text { Lack of physical } \\
\text { proximity makes it }\end{array}$ & $\begin{array}{l}\text { Use of scaffolding } \\
\text { and modeling }\end{array}$ & Google Drive & Asynchronous \\
\hline challenging & & Google Docs & Real-world design \\
\hline Special considerations & Discussion threads & & $\begin{array}{l}\text { projects shared and } \\
\text { student critiques in }\end{array}$ \\
\hline may be needed & $\begin{array}{l}\text { Integrated instructor } \\
\text { videos }\end{array}$ & & LMS \\
\hline Technological issues & & & $\begin{array}{l}\text { Group discussion } \\
\text { topics with }\end{array}$ \\
\hline $\begin{array}{l}\text { Increased instructor } \\
\text { presence needed }\end{array}$ & & & moderators \\
\hline
\end{tabular}

Table 2. Summary of Findings.

The themes that emerged from these findings tended to focus on considerations for design and pedagogical approach. The nuts and bolts of developing or putting together an online course for each was different from teaching online, especially in terms of communication choices, as noted in the first theme.

\section{Online Communication Approaches Matter}

Effective communication with online students is critical, as explained by the participants of this study. Elizabeth clarified that one central challenge of online learning is alleviating anxiety for students, stating that "when you have students face-to-face, you can reassure them and they can read your body language, but when you are in an online setting, all you have is either the synchronous meetings that you hold or the written feedback you provide." The interviews revealed that instructors utilize activities and communications both synchronously and asynchronously. Participants explained the benefits for each method:

- asynchronous communications allow for flexibility;

- synchronous communications remove the factor of delay.

Communications with students occurred through e-mail, videos, and within the LMS (asynchronous communication), but also in online course meetings or through conferencing software (synchronous communication).

"For communication, I use Adobe Connect," said Abby, who holds synchronous online meetings or classes for her students. Features such as the web camera, screen sharing, presentation mode, notes, and drawings are used as well as when students present projects. Elizabeth also uses online synchronous meeting spaces including Adobe Connect, GoToMeeting, and Skype. She likes to hold synchronous meetings for fully online courses. "I think it is important to have as close to a real-time connection as you can." She also likes to use Google Hangouts, Google Docs, and Google Drive for synchronous and asynchronous work and sharing, saying "I like anything where we can share things in real time." While asynchronous approaches are more common in online learning, it is the co-presence of instructor and student that is essential, provided by synchronous communication, according to Abby and Elizabeth.

\section{Challenges and Supports for Online Collaborative Learning}

Participants discussed the challenges that influence online collaborative learning. Time, distance, technology, and connectivity inadequacies affect students. Each instructor interviewed 
has a unique approach to overcome such challenges. Elizabeth believes that technology failure and/or technology difficulties can present challenges to online learning and stated that

It is just a wide-open thing. Of course, any time you are on the Internet, you always run into bandwidth issues...Every time you have a tool that requires a lot of bandwidth, I think you limit what you can do with it...because as much as we like to believe they (students) are placed on a level playing field, the bottom line is not everybody is.

Susan also explained that collaborative learning takes more time online. Collaborative learning can be successful in the online classroom and according to Susan,

It takes lots of planning and preparation and lots of nurturing with those collaborative groups for it to be effective online, in an online setting. I think that's largely because students do not have much experience with it as graduate students in a face-to-face setting, so they do not have anything to transfer in terms of their skills [and experiences in] doing it. They do not know how to do it. They do not know what they're supposed to do in terms of communication, and they'll use technology as the barrier, when it's really not the barrier. They just do not know what to do.

Group work or group projects are often used to facilitate collaborative learning. Each participant in the study spoke of group projects or group work. Elizabeth believes that each student has something unique to offer during group work. Abby believes collaborative learning is possible in the online environment and noted that, "I usually ask my students to work in groups to generate a project or to solve something." However, she expressed concern about equal workload within the groups and as a result recently incorporated a peer review process that students are made aware of at the beginning of the semester. If students understand their level of contribution or effort will be evaluated they may be more conscientious about their role in group work.

When discussing particular collaborative learning tools, Elizabeth said, "I think every tool has inherent benefits and inherent challenges associated with it. I think the key is using the tool appropriately for the circumstance." This is consistent with Gibson's (1977) view of pairing the appropriate learning affordance with the defined needs of a learning task. Such pedagogical effort eases the transition into group work and new technology tools.

\section{Care is at the Core of Online Learner Support}

Participants portrayed relationships with online and face-to-face students similarly. Abby described a good relationship with her online students and believed that they know they can count on her. Susan explained that the relationships with her students in her online courses are not much different than those with her face-to-face students. "We communicate frequently, sometimes as a whole group or small groups, sometimes independently...students feel comfortable contacting me." Elizabeth echoed these feelings, stating that she is an accessible and approachable instructor.

However, because online students are not in the same physical location and learn at different times, additional support is necessary to achieve collaborative learning. The participants therefore provide scaffolding for collaborative activities and online coursework. Elizabeth models expectations for critique sessions. She explained why she does this, saying

You also have to be strategic about that because if you have not laid the foundation for that, if you have not built the rapport, if you have not established yourself as an 
instructor, if you have not modeled what your expectations are. If you have not demonstrated the process at least once or twice, students are so terrified of doing it that they just do not quite know what to do. At particularly undergrad and masters level, I do not like to just throw people into the deep end of the pool. I like to show them how to swim first.

Susan believes that her students do not have anything to transfer from their high school and many earlier college experiences when it comes to collaborating online and they need extra support. She stated that "I'm trying to help them get some experience in this for future courses, because I know it's not going to go away for them, but they're not real crazy about it." Catherine also noted that

I try to make an effort to connect with students and if they do have a certain situation happening, I want them to reach out to me and let me know. It might not affect our coursework but if it does, at least I have a way to help guide them through both my class and how they can handle this outside issue.

Catherine is ardent about establishing a human connection with her online students, which is a hallmark of social constructivist learning experiences. She explained, "You can have a class without that (human connection) but I feel like it's different. It may not be better or worse, but it's not the same." Therefore, she strives to make this connection with her videos. She said, "Because of my videos, I think I also develop a different kind of relationship and this gets at some of the literature on instructor presence in an online class."

Communication with students, accessibility, and instructor presence were priorities for all instructors. Participants are committed to assist and support their students. Each approaches instruction and design with a distinct level of care, believing that it supports students and improves learning. Their availability, affirmations, and authenticity provide students with a strong instructor presence.

\section{Discussion}

All four participants enjoy teaching online and recognize the flexibility offered in this learning environment for themselves and their students, but also discussed various challenges and obstacles that confront online instructors and explained that online teaching may not be a good fit for every instructor. Online collaborative learning is the heart of this case study and each participant defined and explained this type of learning. They described it as a process of working and learning together on an authentic endeavor to build mutual understanding and knowledge. The value of the themes and topics of inquiry are further explained in this section. The perceptions of, and experiences with, online learning, utilization of tools, and pedagogical approaches are used as headings to organize the discussion of the outcomes and summarize the value of the findings. Additionally, a cross comparison of the cases is provided to note commonalities, patterns, limitations, and future research implications.

\section{Perceptions of Online Collaborative Learning}

The overall perception (topic of inquiry 1) that participants expressed regarding collaborative learning in the online classroom is that it can be as effective and occur in the same manner as face-to-face collaborative learning, but requires accommodations that address various 
challenges of online learning, including distance. Each participant in this study continues to refine her approach to providing and improving online collaborative learning.

Susan and Catherine work for the same university and are systematic about their approach to collaborative learning. Their collaborative learning occurs in an asynchronous manner and they utilize an organized and more structured approach. Susan explained that a management-oriented approach works for online collaborative learning. The pedagogical work and clear outcomes Susan provides to students supports them in a manner that allows successful completion of collaborative learning activities. The videos that Catherine uses in her courses to introduce and conclude topics has helped her establish a human connection with her online students and provide an increased instructor presence. These approaches are consistent with prior research (Anderson, 2008; Aragon, 2003; Barkley et al., 2014). Creating an environment where students feel supported and confident is one way to increase teacher presence in the online classroom (Anderson, 2008). Aragon (2003) suggested the following to increase social presence: a. limiting the class size of an online classroom, b. including collaborative learning activities, and c. sharing personal stories and experiences in discussion threads.

In the online environment, instructors serve as both mentors and facilitators (Barr \& Tagg, 1995; Rovai \& Jordan, 2004). Abby and Elizabeth approach collaborative learning from this perspective. While structure in the form of establishing norms, discussing expectations, and objectives are a part of this process, the real time social interactions are essential to their approach. Learning is collaboratively achieved when students work on projects and instructors facilitate. Synchronous communication and activities through online meetings helps to facilitate this approach.

The four participants were exposed to face-to-face collaborative learning in their childhoods. They adapted this experience to the online environment and because of this, understand that students may need extra support to adapt to online collaborative learning and to the less direct instructional approach characteristic of collaborative learning. Susan believes that extra preparation and nurturing is needed for group work or collaborative projects because graduate students do not have the skills or experience working in this way. Abby assumes a facilitator role and believes that adult students know how to work together to collaborate online. She does not want to intervene in this process, but offers support if needed.

Mixed time zones, scheduling concerns, the lack of physical proximity, and technological issues were identified as concerns and challenges for students and instructors. Group projects, which facilitate collaborative learning, can present challenges because students are not in the same location, as they are in a traditional classroom, and because they may be uncomfortable working together as a group. These potential obstacles do not deter study participants in their commitment to collaborative learning. Each participant discussed situations where a collaborative learning activity did not go as anticipated, but these became learning experiences for participants, opportunities to reflect and improve their method for the benefit and success of their students.

Participants described relationships with online students as similar to those with face-toface students. While each connects with students uniquely, all make it clear that they are available for their students and desire open lines of communication. Each participant in the study has a unique way to overcome the inherent challenges of the lack of physical proximity in the online classroom. Communication with their students is a priority, as well as being accessible and 
instilling instructor presence in their online courses. They are committed to assistance, support, and availability for their students.

\section{Experiences with Online Collaborative Learning}

The description of the collaborative learning experiences (topic of inquiry 2) in participants' online classrooms parallels the definition of collaborative learning in the literature. Students work in small groups with less than four members on authentic and real-world problems and projects. Although the level of structure provided varies among participants, all participants utilize scaffolding and/or modeling. Pre-instruction, examples, videos, and critique modeling are used, as "an instructor should provide the guidance required for learner to bridge the gap between their current skill levels and a desired skill level" (Driscoll, 2005, p. 258). The lack of physical proximity makes collaborative learning a challenge, but this can be remedied with increased scaffolding and modeling - creating a foundation for students upon which to build knowledge.

\section{Tools for Online Collaborative Learning}

While participants easily identified the tools they use and responded to questions regarding specific tools (sub-topic of inquiry 1), important discussions related to the effective use of tools. Susan explained that it is "not what the tool does, but how I best use that tool. How can I most effectively use that particular tool in a particular topic or content or assignment activity to help the students learn with that tool. Not from the tool, but with the tool." Elizabeth explained that, for her, each tool has different affordances and she said, "I think every tool has inherent benefits and inherent challenges associated with it. I think the key is using the tool appropriately for the circumstance."

First- and second-order barriers were identified regarding the usability and stability of the tools, the difficulty of managing group learning, and classroom management issues (Donna \& Miller, 2013). Despite the barriers, a teacher who values the use of pedagogies that support collaborative learning is more likely to integrate the necessary tools to facilitate this type of learning (Donna \& Miller, 2013). Abby, Elizabeth, and Catherine mentioned the challenges inherent in the use of technology in an online learning environment: bandwidth issues, Internet connections, and lag during online synchronous meetings. Susan explained that most tools within the Canvas LMS support collaborative learning while Abby instead uses the LMS as delivery of instruction. Synchronous tools, rather than the LMS, are her choice.

\section{Approaches for Online Collaborative Learning}

Participants were equally divided between synchronous and asynchronous collaborative learning opportunities (sub-topic of inquiry 2) and communications provided by the instructors. Catherine and Susan reported more asynchronous activities while Abby and Elizabeth offer more synchronous activities and communication. The asynchronous activities described by Catherine and Susan allow students to complete the activity during a time that is convenient for them, which maintains flexibility for their students. Hrastinski (2008) explained that many students take online courses for the flexible and asynchronous nature that this type of learning provides. Abby and Elizabeth believe synchronous online meetings bring as much of real-time connection to the online classroom as possible, which remove the delay factor.

The term "nurturing" was used in several interviews. Each participant felt strongly about helping and supporting students. Discussions during the demographic portion of each interview revealed the strong appeal of mentoring and camaraderie, which were felt to enhance each other. 
Creating better adults is a major goal of education (Noddings, 2015) and with the emerging theme of care at the core of online learner support from this case study, a deeper investigation into the research of care theory in online learning was defensible. Care theories that emerged in the 1980s with the works of Gilligan (1982) and Noddings (1984) centered on the experiences of women. Care ethics and care theories have been applied in the areas of education, communities, families, and, more recently, global affairs and justice, with the roots of care theory being the fundamental responsibility we have for one another (Noddings, 2012).

Velasquez, Graham, \& Osguthorpe (2013) examined care pedagogy and how caring is experienced in a technology-mediated setting in an online high school. The findings revealed that continuous dialogue, promptness and clarity of the communications are a part of caring pedagogy. The theme online caring presence emerged in Mastel-Smith, Post \& Lake's (2015) study, similar to what emerged in this study with our participants. These studies, together with this case study, support similar findings on communications, affirmations, availability and presence of the instructor, and a human connection in an online setting.

\section{Future Research and Implications for Practice}

Students who work individually and are taught individually miss out on the value of collaborative learning and do not develop fundamental skills necessary for future collaborative work (Brown, Collins \& Duguid, 1989). Students exposed to activities that require working closely with peers in online classes through meaningful collaborative learning and informal conversations acquire deeper thought development and knowledge construction (Barkley et al., 2014; Swan, 2005; Vygotsky, 1978). Approaches beyond direct instruction were integrated into the successful online instruction used by this study's instructors. Therefore, courses should include "some invitation to gather and apply both intellectual and practical knowledge" (Noddings, 2015, p. 235). In an online environment, the manner of "gathering" is different than a traditional learning environment. As revealed here, the general challenges in online learning, including the lack of physical proximity, are hurdles to online collaborative learning. Catherine explained that "we often think about collaborative learning as being distinctively tied to group work, but I really think that in an online classroom that definitely takes on a different meaning." Participants explained that many considerations beyond group work are included in developing opportunities for successful collaborative learning.

The divide between instructor use of synchronous and asynchronous instructional approaches was prominent in the findings. Hrastinski (2008) found that while synchronous and asynchronous learning complement each other, asynchronous online learning better supports cognitive participation, such as increased reflection. A more recent study explained that past and even current research "may no longer be the status quo and online learning environment scholars need to be willing to conceptually change their understanding related to synchronous online learning" (Yamagata-Lynch, 2014, p. 204). Yamagata-Lynch used synchronous communications to engage students in spontaneous discussions and asynchronous communications that allowed students time to reflect and prepare a response to the discussion topics that were designed for a particular week (2014). In another study, it was found that the use of instruction with online constructivist theories that supports synchronous and asynchronous learning fulfills the need for interactive online learning and mitigates the isolation of online learners (Larreamendy-Joerns \& Leinhardt, 2006). The use of both synchronous and asynchronous activities and learning are recommended for online learning, but synchronicity may be the best approach to alleviate the concern of "time" expressed by participants, especially for challenges expressed regarding the 
extra time needed for communications in the online environment and the issue of time or delay in interactions. Synchronous tools and online synchronous meetings remove the delay factor. Future research is recommended to ascertain how synchronous and asynchronous collaborative learning can be used together to better support collaborative learning opportunities.

Collaborative learning will endure and evolve in online learning settings. In keeping with this, Susan believes that students should be prepared for future courses that use collaborative learning. She explained that part of this preparation will require students to work together, a practice they do not typically like to do online. Teachers should therefore set expectations for how students can connect and work, including normative cues to govern their group-based interactions. These social interactions are at the center of the collaborative learning process. Further research should explore whether a progression of integration occurs when instructors move toward the use of collaborative learning in online learning. It is also valuable for instructors to understand whether a progression of acceptance and level of comfort happens for students learning to work together online and to identify potential concerns.

From a care-at-core of online learning perspective, Velasquez et al. suggested, "the technology-mediated context is sufficiently robust to facilitate caring interactions. It demonstrates how caring may be experienced online, including considerations that may differ from face-to face settings" (2013, p. 114). From this, research about online collaborative learning should be explored "through the lens of care" (Noddings, 2012, p. 244). An examination of the perceptions of, and experiences with, care-at-the-core of the learning process should include components of modeling, dialogue, practice, and confirmation, which may enhance perspectives that help improve collaborative learning in online learning. Further, such research can help the field develop a model of care in online teaching and learning from a cognitive perspective to guide the instructional design of individual courses as well as whole programs, as well as pedagogical practice. This model would be valuable for institutions that seek to implement academic coaching and professional development opportunities for online instructors.

\section{Limitations}

There were a few limitations to the study. First, it was conducted through a post-Positivist paradigm and the findings are not intended to generalize; therefore, readers should examine our findings through a lens of transferability to their own situation and context to determine its applicability. Further, this was an exploratory study, so there were only a few participants included prior to expansion in the future, which may be viewed to limit transferability; this challenge may also apply to male readers, because of their lack of participation in the study, although it was sought. Therefore, it is recommended that the same study be conducted with equal participation of male and female participants to determine the extent to which themes remain consistent across gender.

\section{Recommendations}

Based on the findings of this study, we recommend the following regarding the practice of online collaborative learning if the reader is in a similar setting:

- If one teaches courses around message or instructional design, as Catherine and Elizabeth discussed, consider an authentic or real-world design project that combines peer critique. 
- Modeling and scaffolding should be used to provide students with specific examples of the critique process. This can alleviate fear for students new to peer critique.

- Keep groups small, with only three to four students per group, as Susan does. Be flexible about how groups are formed and take into consideration varied time zones.

- To support workload concerns, peer responsibilities, and the effectiveness of group work, consider a peer evaluation. Make students aware that their group members (peers) will evaluate them, such as the approach Abby takes.

- To increase instructor presence in predominantly asynchronous learning and to deliver a human component to your online classroom.

- Consider using short instructor videos for your students, as Catherine does for introducing topics and for topic wrap-ups.

- If you want to utilize a new tool or collaborative learning activity, remember the pedagogical work needed for successful integration.

- The tools integrated to accomplish collaborative learning activities require planning and pedagogical work more important than the tool itself.

- Consider the use of some form of synchronous learning in online courses.

- Synchronous online meetings improve real-time communications, provide a space for groups to meet and interact, and are useful for providing the scaffolding and modeling essential to online collaborative learning.

- Approach the instruction and design of online collaborative learning mindfully, with an overall caring attitude and consideration for learners' experiences.

\section{Conclusions}

Exposing students to activities where they work closely with their peers in online classes through meaningful collaborative learning and informal conversations leads to deeper thought development and knowledge construction (Barkley et al., 2014; Swan, 2005; Vygotsky, 1978). Approaches beyond direct instruction were integrated into the online courses led by this study's participants. Therefore, courses should include "some invitation to gather and apply both intellectual and practical knowledge" (Noddings, 2015, p. 235). In an online environment, the manner of student "gathering" together in groups as well as their process of information seeking often differs from a traditional environment. As noted in our study, the general challenges in online learning, including the lack of physical proximity, are hurdles for online collaborative learning to occur, as has been noted elsewhere (Paulus, Payne, \& Jahns, 2009; Junco, Heiberger, \& Loken, 2011). As Catherine explained: "We often think about collaborative learning as being distinctively tied to group work, but I really think that in an online classroom that definitely takes on a different meaning." Participants discussed many considerations necessary to develop successful collaborative learning beyond group work, including additional time and nurturing, scaffolding, instructional design, and understanding students' comfort level working together online. 
The unique contribution of this study is the emergence of care-at-the-core of online learner support, including nurturing, helping, and supporting students in collaborative learning. This emergent theme is an under-researched area of online learning. The presence of online care and online learning from the care perspective is woven into the findings and top themes in this study. Noddings' $(1984 ; 2015)$ work on care theory is robust and expands across numerous decades and various fields of study. Care in collaborative learning is embedded in the genuine acts and authenticity of the participants of this study. The foundation of the care perspective in online learning helps students tap into their full potential, supports their individual qualities, and builds upon these strengths to aid in the overall success of the individual. By doing so, we hope that online learning can be improved, and student experience can grow and become increasingly positive in the future. 


\section{References}

Al-Rahmi, W., Othman, M. S., \& Yusuf, L. M. (2015). The role of social media for collaborative learning to improve academic performance of students and researchers in Malaysian higher education. The International Review of Research in Open and Distributed Learning, 16(4)

Ally, M. (2008). Foundations of educational theory for online learning. In T. Anderson \& F. Elloumi (Eds.), The theory and practice of online learning. Edmonton, AB: Athabasca University Press.

Anderson, T. (2008). Towards a theory of online learning. In T. Anderson \& F. Elloumi (Eds.), The theory and practice of online learning. Edmonton, AB: Athabasca University Press.

Barkley, E. F., Major, C. H., \& Cross, K. P. (2014). Collaborative learning techniques: A handbook for college faculty. San Francisco, CA: Jossey-Bass.

Bednar, A. K., Cunningham, D., Duffy, T. M., \& Perry, J. D. (1991). Theory into practice: How do we link? In G. J. Anglin (Ed.), Instructional technology: Past, present and future. Englewood, CO: Libraries Unlimited.

Capdeferro, N., \& Romero, M. (2012). Are online learners frustrated with collaborative learning experiences? The International Review of Research in Open and Distributed Learning, $13(2), 26-44$.

Coll, C., Rochera, M. J., \& de Gispert, I. (2014). Supporting online collaborative learning in small groups: Teacher feedback on learning content, academic task and social participation. Computers \& Education, 75, 53-64.

Cyrs, T. E. (1997). Teaching and learning at a distance: What it takes to effectively design, deliver and evaluate programs. San Francisco, CA: Jossey-Bass.

Dabbagh, N. (2005). Pedagogical models for e-learning: A theory based design framework. International Journal of Technology in Teaching and Learning, 1(1), 25-44.

Denzin, N. K., \& Lincoln, Y. S. (2005). Introduction: The discipline and practice of qualitative research. In N. K. Denzin \& Y. S. Lincoln (Eds.), The Sage handbook of qualitative research (pp. 1-32). Thousand Oaks, CA: Sage.

Driscoll, M. P. (1994). Psychology of learning for instruction. Boston, MA: Allyn \& Bacon Publishers.

Erlandson, D. A., Skipper, B. L., Allen, S. D., \& Harris, E. L. (1993). Doing naturalistic inquiry: A guide to methods. Newbury Park, CA: Sage Publications.

Flyvbjerg, B. (2005). Case study. In N. K. Denzin \& Y. S. Lincoln (Eds.), The Sage handbook of qualitative research. Thousand Oaks, CA: Sage.

Gibson, J. J. (1977). The theory of affordances. In R. Shaw \& J. Bransford (Eds.), Perceiving, acting, and knowing: Toward on ecological psychology (pp. 67-82). Book Section, Hillsdale, NJ: Erlbaum and Associates.

Gilligan, C. J. (1982). In a different voice. Cambridge, MA: Harvard University Press. 
Glaser, B. G. \& Strauss, A. L. (1967). The discovery of grounded theory: Strategies for qualitative research. Transaction Publishers.

Guba, E. G., \& Lincoln, Y. S. (1994). Competing paradigms in qualitative research. In N. K. Denzin \& Y.S. Lincoln (Eds.), Handbook of qualitative research, 105-117. Thousand Oaks, CA: Sage.

Hämäläinen, R., \& Vähäsantanen, K. (2011). Theoretical and pedagogical perspectives on orchestrating creativity and collaborative learning. Educational Research Review, 6(3), 169-184.

Hiltz, S. R., Coppola, N., Rotter, N., Turoff, M., \& Benbunan-Fich, R. (2000). Measuring the importance of collaborative learning for the effectiveness of ALN: A multi-measure, multi-method approach. Journal of Asynchronous Learning Networks, 4(2), 103-125.

Hrastinski, S. (2009). A theory of online learning as online participation. Computers \& Education, 52, 78-82.

Jonassen, D. H. (1999). Designing constructivist learning environments. In C. M. Reigeluth (Ed.), Instructional design theories and models: A new paradigm of instructional theory (Vol. 2, pp. 215-239). Book Section, Mahwah, NJ: Lawrence Erlbaum Associates, Publishers.

Junco, R., Heiberger, G., \& Loken, E. (2011). The effect of Twitter on college student engagement and grades. Journal of Computer Assisted Learning, 27(2), 119-132.

Kai-Wai Chu, S., \& Kennedy, D. M. (2011). Using online collaborative tools for groups to coconstruct knowledge. Online Information Review, 35(4), 581-597.

Kang, M. \& Im, T. (2005). Factors of learner-instructor interaction which predict perceived learning outcomes in online learning environment. Journal of Computer Assisted Learning, 29, 292-301.

Keengwe, J. \& Georgina, D. (2012). The digital course training workshop for online learning and teaching. Education and Information Technologies, 17(4), 354-379.

Khwaja, T., \& Eddy, P. L. (2015). Using Mendeley to support collaborative learning in the classroom. I-Manager's Journal of Educational Technology, 12(2), 19.

Kim, K., \& Bonk, C. J. (2006). The future of online teaching and learning in higher education: The survey says. Educause Quarterly, 29(4), 22.

Johnson, C. J. (2013). Evaluation of a hybrid mathematics methods course for novice teachers. International Journal of Online Pedagogy and Course Design, 3(1), 33-52.

Larreamendy-Joerns, J. \& Leinhardt, G. (2006). Going the distance with online education. Review of Educational Research, 76(4), 567-605.

Leidner, D. E., \& Jarvenpaa, S. L. (1995). The use of information technology to enhance management school education: A theoretical view. MIS Quarterly, 19(3), 265-291.

Lincoln, Y. S. (1985). Naturalistic inquiry (Vol. 75). Egon G. Guba (Ed.). Newbury Park, CA: Sage.

Major, C. H. (2015). Teaching online: A guide to theory, research, and practice. Baltimore, MD: JHU Press. 
Mastel-Smith, B., Post, J., \& Lake, P. (2015). Online teaching: Are you there, and do you care? Journal of Nursing Education, 54(3), 145-151.

Moore, M. G., \& Kearsley, G. (2012). Distance education: A systems view of online learning. Belmont, CA: Wadsworth.

Noddings, N. (1984). Caring: A feminine approach to ethics and moral education. Berkeley and Los Angeles, CA: University of California Press.

Noddings, N. (2012). Philosophy of education. Boulder, CO: Westview Press.

Noddings, N. (2015). A richer, broader view of education. Society, 52(3), 232.

O’Neill, S., Scott, M., \& Conboy, K. (2011). A Delphi study on collaborative learning in distance education: The faculty perspective. British Journal of Educational Technology, 42(6), 939-949.

Oncu, S., \& Cakir, H. (2011). Research in online learning environments: Priorities and methodologies. Computers \& Education, 57(1), 1098-1108.

Palloff, R. \& Pratt, K. (1999). Building learning communities in cyberspace: Effective strategies for the online classroom. San Francisco: Jossey-Bass.

Paulus, T. M., Payne, R. L., \& Jahns, L. (2009). ““'Am I making sense here?”: What blogging reveals about undergraduate student understanding. Journal of Interactive Online Learning, 8(1), 1-22. Retrieved from www.ncolr.org/jiol

Ravitch, S., \& Mittenfelner Carl, N. (2016). Qualitative research: Bridging the conceptual, theoretical, and methodological (1st ed.). Los Angeles, CA: Sage Publications, Inc.

Rovai, A. P. (2004). A constructivist approach to online college learning. The Internet and Higher Education, 7(2), 79-93.

Saldaña, J. (2009). The coding manual for qualitative researchers. Thousand Oaks, CA: Sage Publications.

Savery, J. R. \& Duffy, T. M. (1995). Problem-based learning: An instructional model and its constructivist framework. Educational Technology, 35, 31-38.

Smith, P. L. \& Ragan, T. J. (2005). Instructional Design. $3^{\text {rd }}$ Edition. US: John Wiley \& Sons.

Stake, R. E. (1995). The art of case study research. Thousand Oaks, CA: Sage Publications.

Stodel, E. J., Thompson, T. L., \& MacDonald, C. J. (2006). Learners' perspectives on what is missing from online learning: Interpretations through the community of inquiry framework. International Review of Research in Open and Distance Learning, 7(3), 1-22.

Swan, K. (2005). A constructivist model for thinking about learning online. In J. Bourne \& J. C. Moore (Eds.), Elements of Quality Online Education: Engaging Communities. Needham, MA: Sloan-C.

Tam, M. (2009). Constructivism, instructional design, and technology. In Willis, J. W. (Ed.). Constructivist Instructional Design (C-ID): Foundations, Models, and Examples. (6181). Charlotte, NC: Information Age Publishing.

Thompson, L., \& Ku, H. (2006). A case study of online collaborative learning. The Quarterly Review of Distance Education, 7(4), 361-375. 
Van Bruggen, J. (2005). Theory and practice of online learning. British Journal of Educational Technology, 36(1), 111-112.

Velasquez, A., Graham, C. R., \& Osguthorpe, R. (2013). Caring in a technology-mediated online high school context. Distance Education, 34(1), 97-118.

Vonderwell, S. \& Turner, S. (2005). Active learning and pre-service teachers' experience in an online course: A case study. Journal of Technology and Teacher Education, 13, 65-84.

Von Glasersfeld, E. (1989). Cognition, construction of knowledge, and teaching. Synthese, 80(1), 121-140.

Vuopala, E., Hyvönen, P., \& Järvelä, S. (2016). Interaction forms in successful collaborative learning in virtual learning environments. Active Learning in Higher Education, 17(1), 25-38.

Vygotsky, L. (1978). Mind in society. Cambridge, MA: Harvard University Press.

Xiong, Y., So, H., \& Toh, Y. (2015). Assessing learners' perceived readiness for computersupported collaborative learning (CSCL): A study on initial development and validation. Journal of Computing in Higher Education, 27(3), 215-239.

Yin, R. K. (2014). Case study research: Design and methods. Thousand Oaks, CA: Sage Publications. 